\author{
Kalaman 0. \\ Ph.D. in Economics, Associate Professor \\ Department of Management and Logistics \\ E-mail: kalaman.olga@umail.ru \\ Babenko K. S \\ The student of Faculty of Innovative Nutrition Technologies, \\ Restaurant and Hotel Business \\ Odessa National Academy of Food Technologies \\ Kanatna str., 112, Odesa, Ukraine, 65039 \\ E-mail: ksu babenko@mail.ru
}

\title{
THE DEVELOPING TRENDS OF THE ITALIAN AND UKRAINIAN VITICULTURE AND WINERIES
}

The world experience of viticulture development and winemaking is analyzed in this article. It is established that the experience of Italy is the most acceptable example for Ukrainian winegrowers. The analysis of wine industry development in Ukraine and Odessa region is carried out general. The dynamics of grape production and the processing of wine materials in different areas as well as the inside and outside factors making impact on development of wineries are also analyzed. ticulture.

Keywords: competitive ability, wine industry, wineries, winemaking, processing of wine materials, vi-

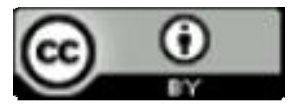

This work is licensed under a Creative Commons Attribution 4.0 International License http://creativecommons.org/licenses/by/4.0/

Statement of the problem and its connection with important scientific and practical tasks. The wine industry is the perspective direction of economics development in Ukraine that has a special place among a lot of leading countries in the world due to the favorable soil and climate conditions and sufficient provision with labor and other resources. However, today there are a lot of problems for stable and efficient work: general economic depression in the country, a low supply of manufactures with raw material, violations of equal mutual relations between raw material producers and wineries, high competition on the ready-made products market, unprotected domestic producers of raw materials and ready-made products, lack of support from the state, low quality products in the home market etc.

The analysis of the latest publications on the problem. A lot of Ukrainian scientists investigated wine making problems: Avidzba A.M., Buzni A.N., Garkusa O.M., Marmul L.O., Matchina I. G., Rybincev V.A., Sabluk P.T., Cherven I.I. and others.

Forming of the aims of the research. However, it's important to note that the realities of Ukrainian companies of viticulture industry have a tendency to constant changes. Therefore, it's advisable to analyze current trends timely and to identify potential for Ukrainian wineries development taking into account the Italian winemaking.

Giving an account of the main results and their substantiation. Wine can be considered as one of the first alcohol drinks, while winemaking - the oldest industry. A great amount of the Greek, Roman, Persian,
Syrian and others legends mention the origin of wine and winemaking development.

Viticulture and winemaking have always been the important agronomic industry in Ukraine. Occupying a small share in agricultural land, this industry significantly has influence on the level of social-economic development of the regions. The history of viticulture and winemaking development in Ukraine dates back to ancient times. The images of grape bunches on some coins in III and II centuries BC in Tira city show that viticulture and winemaking were the most important kinds of work there. During two and a half millennium the periods of blooming alternated with troughs and complete loss of viticulture or winemaking, resulted from the military operations or underestimation of this high profitable and such necessary industry [1].

Various historical sources testify that viticulture and winemaking began its development as the agricultural industry in the territory of modern Ukraine, particularly in the south region in the 6th century BC. From that time until today the development of viti-wineculture in modern Ukraine has had a lot of ups and downs connected not only with historical moments, but also with a human factor [1].

In 2008, Ukraine became the $152 \mathrm{~d}$ full member of the world Trade Organization, and this fact opened the way out of the country on the international market with its hard competition. At that moment, Ukraine occupied the following positions in the production of grapes in the world and the EU countries: the specific gravity of the total area of domestic vineyards made up $1,0 \%$ and $2,0 \%$, 
crop capacity $-64,5 \%$ and $83,7 \%$, gross vintage $-0,62 \%$ and $1,7 \%$ correspondingly [5].

Therefore, the domestic viticulture and wine industry must be up to the world standards of production and quality in order to occupy a fitting place among world producers. The achievement of specified goals is only possible in case the industry output is on the sufficiently high level of development that induces to systematic search by scientists, practical farmers, winegrowers and winemakers together with the state support that provides ways and methods for improving the economic, technological, social and other kinds of industry efficiency.

After the entrance of Ukraine into WTO, the competitive ability of domestic producers plays the key role, because they are the leading link in the economic development of the country. It's its condition that makes impact not only on the economics, but also on the international position, the image and attractiveness of the country. However, wine industry not only in Ukraine, but also in the whole the world has difficulties nowadays. According to OIV, there are 9,5-10,0 mln. he of vineyards. The annual total production of grapes is $60-70 \mathrm{mln}$ tonnes, wine $-280 \mathrm{mln}$ gl. The main wine producers are Italy (up to $45 \mathrm{mln}$ gl.), France (up $44 \mathrm{mln}$.) and Spain (up 40 $\mathrm{mln})$.In general, the EU produces $146 \mathrm{mln} \mathrm{gl}(52 \%)$.

In 2015 in Ukraine the area of vineyards estimates $-45,4$ thousand he, bearer yards $-41,8$, gross vintage - 386,3thousand tonnes (81\% till 2014 p.) (pic. $1)$.

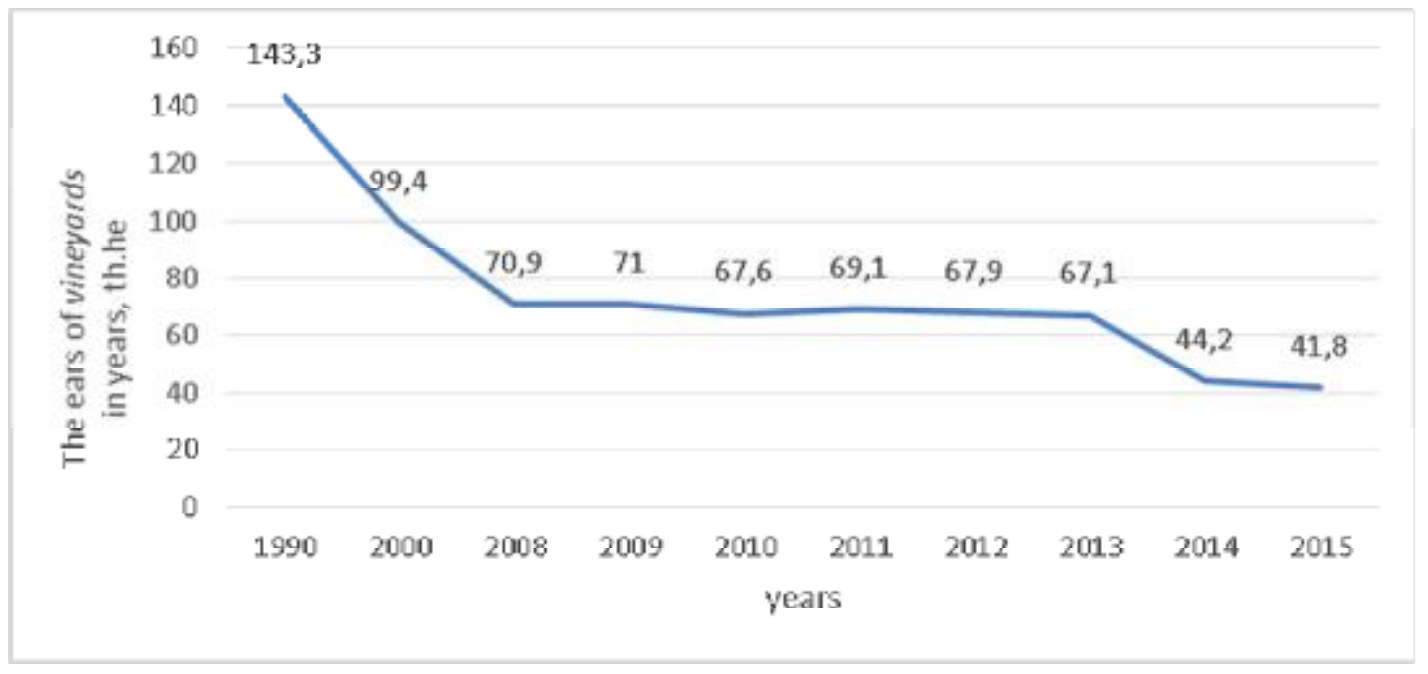

Pic.1. The area of vineyards in Ukraine in 1990-2015 y., thousand he [3]

Independent Ukraine inherited vitiviniculture in a very bad condition. During the last decade negative trends in Ukrainian viticulture continued, that, is as a result, led to the present crisis in this industry, which is characterized by high thinness of existing vineyards, lower volume of seedling production, that are steady to pathogens, spreading mediocre sorts with low consumer properties etc. It resulted in a decrease in grape production.

It should be mentioned that, despite the significant natural grape and wine potential in Ukraine, the production of grapes is concentrated not in all regions, but only in grape zones, where nature creates favorable climate conditions and suitable grounds for growing vine rods. According to the law of Ukraine "About grapes and grape wine" the term of the zone of wine growing is defined in such a way: the geographical territory of Ukraine with suitable agroecological conditions for cultivation of culture of grapes [6].

In the last Grape cadastre (2010 year) the 15 zones of wine growing (macrozones), which are the basis of sorts regions, and 58 natural wine regions (micro- zones) of the widest distribution, and their specialization of viticulture and winemaking and range of grapes, were picked out. Particularly, there are 3 macrozones and 16 microzones in Odessa region, in Mykolaiv - 2 and 7, in Zakarpattia - 1 and 12, in Zaporizhzhia - 1 and 16, in Kherson - 2 and 10 correspondingly [7].

Apparently, the annual rates of the areas of vineyards reduction including fertile age for the whole analyzed period fluctuate, within approximately the same ranges without clearly expressed regularity. The sharp decrease in vineyard areas in 2015 was partly explained by the lack of statistics on grape growing in the territory of the Autonomous Republic of Crimea and was not significant from the objective point of view.

The south of Ukraine received the most territorial spreading as industry, taking into consideration ground-climate conditions, (Odessa, Mykolaiv, Kherson and Crimea), in Zaporizhzhia region and in the west region (Zakarpattia), which share in 2015 accounted 89,9\% of specific gravity of vineyards in the fertile age. (table $1)$. 
Vineyards area in certain regions (in all categories),thousand he [3]

\begin{tabular}{|l|c|c|c|c|c|c|c|c|c|c|c|c|}
\hline \multirow{2}{*}{ Regions } & 1990 & 2000 & 2008 & 2009 & 2010 & 2011 & 2012 & 2013 & 2014 & 2015 & \multicolumn{2}{|c|}{$\begin{array}{c}2015 y \text { in \% } \\
\text { till }\end{array}$} \\
\hline $\begin{array}{l}\text { Ukraine } \\
\text { in general }\end{array}$ & 143,3 & 99,4 & 70,9 & 71,0 & 67,6 & 69,1 & 67,9 & 67,1 & 44,2 & 41,8 & 29,17 & 94,57 \\
\hline Zakarpattia & 5,5 & 4,9 & 4,1 & 4,2 & 3,9 & 4,0 & 3,7 & 3,9 & 3,7 & 3,7 & 67,27 & 100,00 \\
\hline Zaporizhzhia & 1,6 & 0,4 & 0,4 & 0,3 & 0,3 & 0,4 & 0,4 & 0,4 & 0,4 & 0,3 & 18,75 & 75,00 \\
\hline Mykolaiv & 10,4 & 6,8 & 5,0 & 5,4 & 5,3 & 5,2 & 5,6 & 5,7 & 5,8 & 5,8 & 55,77 & 100,00 \\
\hline Odessa & 55,1 & 40,3 & 30,2 & 30,3 & 28,0 & 29,4 & 29,1 & 28,5 & 27,5 & 25,5 & 46,28 & 92,73 \\
\hline Kherson & 15,6 & 5,4 & 5,1 & 4,9 & 4,5 & 5,4 & 5,2 & 5,6 & 5,1 & 4,8 & 30,77 & 94,12 \\
\hline Crimea & 53,7 & 40,1 & 24,5 & 24,2 & 23,8 & 17,9 & 17,3 & 16,2 & - & - & - & - \\
\hline
\end{tabular}

Data analysis proves that the size of the vineyards in the fertile age had had a strong tendency to decrease for more than 20 years, and as a result - it reached the figure 41,8 thousand he in 2015 , that is only $29,17 \%$ from the level in 1990 . It should be noted that Odessa region, which in 1990 (excluding indicators for Crimea) covered $61,5 \%$ of the area in Ukraine and saved this regularity in 2015 (61\%). Kherson region had a much smaller area of plantations whose share in 2015 was only $11,5 \%$ from the index in Ukraine. The greatest losses of plantings in the vineyards due to the absolute value were in Odessa region ( - 29,6 thousand he till the index in 1990), and due to the fall rate - Zakarpattia, which lost $67,27 \%$ of the vineyards area in comparison with 1990 .

In general there is a tendency to an overall reduction of vineyards almost every year in Ukraine, including fruit-bearing age. In addition, there is a general decrease in laying of young vineyards that don't compensate the areas withdrawn from economic circulation. The research found that the reasons of insufficient laying of vineyards in recent years, in comparison with the volume of write-off plantations, were both financial and purely psychological. The first include the difference in terms of revenues from the state budget for industry support (including allocation tax on development of viticulture, horticulture and hop) and terms of the work and actual needs in funds. After all, the state compensation of costs on planting vineyards was only in the $4^{\text {th }}$ quarter of this year, while works on the plantations are always held at the beginning of the year in early spring on their own money or business credit. In addition, a very negative situation for the grapes producers with timely receipt of these funds has appeared recently. Thus, according to the Chamber in 2002 year, the Ministry of Agrarian Policy and Food in the presence of the remaining public assignment in the amount of 172,2 million UAH and revenues collection on development of viticulture, horticulture and hop including UAH $1 \mathrm{mlrd} 75,0 \mathrm{mln}$, on the state support for the development of viticulture, horticulture and hop only UAH $309,2 \mathrm{mln}$, or $24,8 \%$ of available resources and $28,8 \%$ of the plan were used [8].

Among the psychological reasons, why the growers were unwillingly engaged in renewal of vineyards, we can admit pessimistic producers' expecta- tions regarding the level and terms of compensation costs on new laying vineyards from the state; that, according to the above data, has logical basis.

It should be noted separately, that from January 1,2013 the rules on the administration fee were relocated to the Tax Code Ukraine, and from 1 January 2015 according to the Law of Ukraine "About amendments to the Tax Code Ukraine and some legislative acts Ukraine on the tax reform" tax on development of viticulture, horticulture and hop was cancelled in general. Instead, retailers of alcohol beverages from 01.01.2015 year started to pay $5 \%$ excise tax, which is directed to the local budgets, and therefore its distribution also raises questions today [9].

One of the components that have impact on the efficiency of development in modern domestic viticulture and its weak point is the variety composition of vineyards both table and technical directions.

In the vast majority of domestic industries, viticulture is represented by the old and low productive plantations table grapes, which now can't satisfy demand on fresh grape production and need updating. A major disadvantage of table viticulture in Ukraine is also a small share in the industrial assortment of varieties, which have high product quality in the early ripening period. On the one hand, it is by increasing the area of grapes sorts during a very early and an early ripening terms, normative consumption of fresh grapes could be achieved by population, and, on the other hand, the increasing profitability of wine growing enterprises at the expense high prices for the early grape production. Therefore, we think that the expansion of area for early ripening varieties of table grapes is an increasing reserve of economic efficiency of wine growing enterprises.

Technical grape sorts that make up the basis of winemaking, occupy almost 73 thousand he $(84,4 \%$ of all plantings). The sort state of technical grapes is presented by 103 varieties. Among the technical grades that are grown in Ukraine, the largest area belonged to: Rkatsiteli - 16\%, Aligote - 13,2\%, Caberne Sauvignon $11,6 \%$, Chardonnay - 4,1\%, Merlot - 3,9\%, Sauvignon Green - 3,7\%, Odessa Black - 3, Saperavi - 2,1\%, Riesling - 2,1\%, White Sukhomlinsky - 2\% [5]. 
As we can see, other 93 sorts covered $38,0 \%$ of the area. The area under these sorts range from more than 1 thousand he and less than 100 he. Despite such a great number of varieties, the lack of champagne, red and aboriginal varieties is observed. It means that the structure of varietal vineyards in the farms of Ukraine needs improvements, optimization placement and specialization by certain enterprises and in the wine growing regions. In comparison, only 12 varieties of grapes for winemaking exist in Germany [5].

In terms of priority of Ukrainian winemaking development, in the direction of wine production with controlled name of the original place, and varietal wine grapes the number of varieties should be reduced, that ensures the quality and compatibility of domestic wine production. According to the State Register of plant varieties suitable for widening in Ukraine in 2015, among the presented 61 grape varieties, only $27(44,3 \%)$ technical and $6(9,8 \%)$ wine-table are suitable for cultivation in Ukraine [10].

One more weak link in the wine growing industry in Ukraine is clearly picked out - the nursery state. In all wine growing countries the laying of new and reconstruction of already existing vineyards is made only by certified varieties. The network of vine nurseries In Ukraine has almost completely been destroyed. Today, only Odessa, Kherson and Zakarpattia regions host the farms that practice nursery. As a result of the suspension of planned vineyards reconstruction and the absence of need in the grafted plant material, almost a complete decline of nursery base has been observed. Those remaining breeding grounds are not in the best condition, as this direction of the industry is one of the energy- and resource-intensive, so nowadays the cost on planting material has dramatically increased and its production has gradually become unprofitable.

Varietal structure of vineyards in the Ukrainian farms needs streamline placement optimization and specialization both in individual companies and in the natural wine regions. Currently the control over the presence and condition of the plantation associations, industrial associations, agricultural specialists, winemakers is almost lost. State and farm enterprises, often without the consent of processors and producers of wine products, develop stubbing plantations, including valuable grape varieties used for making the high-quality wines and its other products [3].

Another reason for lower productivity of vineyards is their thinness - down to $20 \%$. This percentage of thinness is equal to eliminating sales of about $13-14$ thousand he of agricultural lands and the annual failure (with an average yield) 93,9 - 100 thousand tons of grapes [5].

Another problem that hinders the stable development of the domestic viticulture and winemaking in Ukraine, from our point of view, is a large proportion of old vineyards. The critical age of the vines in Ukraine accounts only 30 - 40 years (in comparison with - the leading countries of winemaking - France, Italy, where there are modern production technologies and the productive age of the vines reaches more than 50 years). In
2008 , the largest area was occupied by vineyards aged from 26 to 40 years $(34,6 \%$ from the total area of vineyards). Vineyards in the most productive age between 5 - 10 and 11 - 25 years accounted respectively $17,1 \%$ and $20,7 \%$ from the total area. The proportion of young plantations under 5 years was $26,7 \%$ [5].

Therefore, an essential part of vineyards in Ukraine today is inefficient and can't be effective in forming the competitive viticulture and winemaking. It should be understood that every year the number of vineyards in Ukraine is growing, correspondingly the question of speed concerning repair and restoration of the vineyards requires immediate resolution. According to the scientific-accurate system of wine part the young vineyards must make at least $20 \%$, and the annual renewal must provide $5 \%$ of existing plantations, so, according to our estimates, no less than 2 thousand he of new vineyards should be laid in Ukraine every year.

In our opinion, insufficient high level of land reform in Ukraine and not fully completed issue of land in the legislation prevents reproduction of domestic vineyards and winemaking development. After sharing the land without right of property winegrowers today aren't at risk to invest in the industry taking into account that the vine is a perennial culture with a long payback period. As a result, part of the vineyards today isn't cultivated, that can't positively effect on the winemaking in the country. The analysis shows that some farms in Kherson region, being reported to the state statistics and available for the vineyards, don't show the resulting yield. On the one hand, in order to improve the situation, from our point of view, the land legislation must be brought in compliance with the time, considering the interests of the state and farmers as quick as possible. On the other hand, we consider, it's necessary to foreknow responsibility for disfigurement and falsification of statistics on business entities.

Conclusions and prospects of the further investigations.To improve the efficiency of domestic wine growing, it's important to start production of containers required to collect and realize table grapes, expanding the network of refrigerators for short and long-term storage, and the development of material database industry, including provision of equipment for effective care of the vineyards and harvest. Low status providing the wine growing industry with equipment is one of the main factors (excluding unfavorable natural conditions), in recent years, resulting in significant yield losses and reduction of the efficiency in the wine growing enterprises. In recent years, investment in the industry gradually declined, and in 2015, according to the official statistics, capital investment in crop long-term biological assets in Ukraine wasn't carried out [3].

Analyzing the current state of domestic winemaking, the industry has some specific features that distinguish it from other sectors of agriculture. First of all, it is a complete dependence of the results of winemaking from the quality and quantity of grapes grown that is the state of viticulture. At the same time, the vine is the plant, as a result of the cultivation of which a lot depends on climate-weather conditions, state of soil and temperature 
in certain periods of growth and development. It requires

products, including variety cut. a very careful approach to the territorial location of wine

\section{References}

1. Istoriia vynohradarstva. Retrieved February, 2017, from http://vinograd.info/info/grozdya-zdorovya/ istoriya-vinogradarstva.html

2. Stan vynorobnoi haluzi u sviti. Retrieved February, 2017, from http://take-profit.org/economicnews.php

3. Derzhavnyi komitet statystyky - 2015r. Retrieved February, 2017, from http://www.ukrstat.gov.ua/

4. Myrovoi vynnыi rыnok: pereraspredelenye syl. Retrieved February, 2017, from http://ubr.ua/market/agricultural-market/vinnyi-rynok-otrezvliaushie-tendencii-261254

5. Prysiazhniuka, M. V., Zubtsia, M. V., Sabluka, P. T., Mesel-Veseliaka, V. I., \& Fedorova, M. M. (2011). Ahrarnyi sektor rozvytku Ukrainy (stan i perspektyvy rozvytku). K.: NNTs IAE.

6. Zakon Ukrainy «Pro vynohrad ta vynohradne vyno» vid 16.06.2005 roku № 2662-IV: za stanom na 04.09.2014 r. (n.d.). Retrieved February, 2017, from http://zakon3.rada.gov.ua/laws/show/2662-15/page

7. Vynohradnyi kadastr Ukrainy . (2009). K.: Minahropolityky, UAAN, Tsentr derzhrodiuchist.

8. Vysnovky shchodo vykonannia Derzhavnoho biudzhetu Ukrainy za 2012 rik . (2012). Retrieved February, 2017, from http://www.acrada.gov.ua/doccatalog/document/16741935/Visnovok 2012.pdf

9. Pererobka vynohradu ta vyrobnytstvo vynomaterialiv u 2015 rotsi. Ekspres-vypusk vid 14.01.2016 r. №2/0/06.2vn-15. Derzhavna sluzhba statystyky Ukrainy . (2016). Retrieved 2017, from http://www.ukrstat.gov.ua

10. Haluzeva Prohrama rozvytku vynohradarstva ta vynorobstva Ukrainy na period do 2025 roku. Nakaz Minahropolityky Ukrainy, Ukrainskoi akademii ahrarnykh nauk vid 21.07.2008 roku № 444/74. (n.d.). Retrieved February, 2017, from http://search.ligazakon.ua/l_doc2.nsf/link1/FIN40145.html

11. Popova, M. M. (2013). Suchasnyi stan i tendentsii rozvytku vynohradarsko - vynorobnoi haluzi v Ukraini. Visnyk Kharkivskoho natsionalnoho ahrarnoho universytetu, 4, 199-207.

12. Derzhavnyi reiestr sortiv roslyn prydatnykh dlia poshyrennia v Ukraini na 2015 rik. . (2015). K.: Derzhavna veterynarna ta fitosanitarna sluzhba Ukrainy.

Received 03 February 2017

Approved 17 February 2017

Available in Internet 31.03.2017

Каламан О.Б.

кандидат экономических наук, доцент

кафедра менеджмента и логистики

E-mail: kalaman.olga@umail.ru

Бабенко К.C.

Студентка факультета инновационных технологий питания и ресторанно-отельного бизнеса

Одесская национальная академия пищевых технологий

ул. Канатная, 112, г. Одесса, Украина, 65039

E-mail- ksu babenko@mail.ru

\section{ТЕНДЕНЦИИ РАЗВИТИЯ ВИНОГРАДАРСТВА И ВИНОДЕЛИЯ УКРАИНЫ И ИТАЛИИ}

В статье проведен анализ мирового опыта развития виноградарства и виноделия. Выявлены общие тенденции в процессе его развития и становления. Показаны сложные этапы украинского виноделия. Особое внимание уделено проблемам виноградарства страны. Отображена зависимость готовой продукции от ряда факторов таких, как проблемы законодательной базы, недостаточного финансирования виноградарства и винодельческой отрасли, отсутствия необходимой поддержки на государственном уровне, неправильной политики в сфере выращивания конкретных сортов и других значимых моментов. Поэтому, как наиболее оптимальный для использования, предлагается опыт Италии в винодельческой отрасли.

В процессе проведенных исследований установлено, что действительно опыт Италии является наиболее приемлемым примером для украинских виноделов. Это касается как производства виноматериалов, так и готовой винодельческой продукции. Однако, в таком использовании также присут- 
ствуют ряд важных аспектов. В частности, на европейском рынке далеко не все сорта, районированные в Украине, пользуются спросом. При этом, следует уделить особое значение популярности производства сладких и полусладких вин для внутреннего украинского рынка.

В подавляющем большинстве отечественных виноградарских хозяйств представлены старые насаждения и малопродуктивные столовые сорта, которые сегодня уже не могут удовлетворить спрос на свежую продукцию виноградарства, и требуют обновления. Существенный недостаток столового виноградарства в Украине - это небольшой удельный вес в промышленном наборе сортов раннего срока созревания, которые имеют высокие товарные качества. Именно за счет увеличения площадей сортов винограда сверхраннего, очень раннего и раннего сроков созревания можно было бы достичь нормативного потребления населением свежего винограда, с одной стороны, и повышение прибыльности виноградарских предприятий за счет высокой цены на раннюю виноградную продукцию, с другой стороны. По мнению авторов, расширение площадей под раннеспелый сорт столового винограда является резервом повышения экономической эффективности деятельности виноградарских предприятий. Поэтому в статье рассмотрены основные направления развития самой передовой винодельческой области - Одесской.

На основе проведенного анализа развития винодельческой отрасли в Украине и Одесской области сделаны выводы о перспективах и стратегическом значении виноделия для Украины. Для сравнения также проанализирована динамика производства винограда и переработки виноматериалов в различных областях страны. Отдельно выделены внутренние и внешние факторы, влияющие на развитие винодельческих предприятий.

Ключевые слова: конкурентоспособность, винодельческая отрасль, винодельческие предприятия, производство вина, переработка виноматериалов, виноградарство.

Каламан О.Б.

кандидат економічних наук, доцент кафедра менеджменту і логістики

E-mail: kalaman.olga@umail.ru

Бабенко К.C.

Студентка факультету інноваційних технологій харчування і ресторанно-готельного бізнесу

Одеська національна академія харчових технологій

вул. Канатна, 112, м. Одеса, Україна, 65039

E-mail: ksu babenko@mail.ru

\section{ТЕНДЕНЦІЇ РОЗВИТКУ ВИНОГРАДАРСТВА І ВИНОРОБСТВА УКРАЇНИ ТА ІТАЛІї}

У статті проведено аналіз світового досвіду розвитку виноградарства і виноробства. Виявлено загальні тенденції в процесі його розвитку і становлення. Показані складні етапи українського виноробства. Особливу увагу приділено проблемам виноградарства країни. Відображено залежність готової продукції від ряду фракторів таких, як проблеми законодавчої бази, недостатнє фрінансування виноградарства і виноробної галузі, відсутність необхідної підтримки на державному рівні, неправильної політики в ссрері вирощування конкретних сортів і інших значущих моментів. Тому, як найбільш оптимальний для використання, пропонується досвід Італії у виноробній галузі.

У процесі проведених досліджень встановлено, що дійсно досвід Італії є найбільш прийнятним прикладом для українських виноробів. Це стосується як виробництва виноматеріалів, так і готової виноробної продукції. Однак, в такому використанні також присутні ряд важливих аспектів. Зокрема, на європейському ринку далеко не всі сорти, районовані в Україні, користуються попитом. При цьому, слід приділити особливу значення популярності виробництва солодких і напівсолодких вин для внутрішнього українського ринку.

У переважній більшості вітчизняних виноградарських господарств представлені старі насадження і малопродуктивні столові сорти, які сьогодні вже не можуть задовольнити попит на свіжу продукцію виноградарства, і потребують оновлення. Істотний недолік столового виноградарства в Україні - це невелика питома вага в промисловому наборі сортів раннього терміну дозрівання, які мають високі товарні якості. Саме за рахунок збільшення площ сортів винограду надранніх, дуже раннього і раннього термінів дозрівання можна було б досягти нормативного споживання населенням свіжого винограду, з одного боку, і підвищення прибутковості виноградарських підприємств за рахунок високої ціни на ранню виноградну продукцію, з іншого боку. На думку авторів, розширення площ під ранньостиглий 
сорт столового винограду є резервом підвищення економічної ефективності діяльності виноградарських підприємств. Тому в статті розглянуті основні напрями розвитку самої передової виноробної області - Одеської.

На основі проведеного аналізу розвитку виноробної галузі в Україні та Одеській області зроблені висновки про перспективи і стратегічне значення виноробства для України. Для порівняння також проаналізовано динаміку виробництва винограду і переробки виноматеріалів в різних областях країни. Окремо виділені внутрішні і зовнішні чинники, що впливають на розвиток виноробних підприємств.

Ключові слова: конкурентоспроможність, виноробна галузь, виноробні підприємства, виробництво вина, переробка виноматеріалів, виноградарство.

\section{Література}

1. Історія виноградарства. [Електронний ресурс]. - Режим доступу: http://vinograd.info/info/grozdyazdorovya/ istoriya-vinogradarstva.html

2. Стан виноробної галузі у світі. [Електронний ресурс]. - Режим доступу: http://takeprofit.org/economicnews.php

3. Державний комітет статистики - 2015p. [Електронний ресурс]. - Режим доступу: http://www.ukrstat.gov.ua/

4. Мировой винный рынок: перераспределение сил [Електронний ресурс]. - Режим доступу: http://ubr.ua/market/agricultural-market/vinnyi-rynok-otrezvliaushie-tendencii-261254

5. Аграрний сектор розвитку України (стан і перспективи розвитку)/ [Присяжнюк М.В., Зубець М.В., Саблук П.Т., та ін.] ; за ред. М.В.Присяжнюка, М.В.Зубця, П.Т.Саблука, В.Я. Месель-Веселяка, М.М.Федорова. - К.: ННЦ IAE, 2011. - 1008 c.

6. Закон України «Про виноград та виноградне вино» від 16.06.2005 року № 2662-IV: за станом на 04.09.2014 р. [Електронний ресурс]. - Режим доступу: http://zakon3.rada.gov.ua/laws/show/2662-15/page

7. Виноградний кадастр України / Мінагрополітики, УААН, Центр держродючість. - К., 2009 р. - 100 c.

8. Висновки щодо виконання Державного бюджету України за 2012 рік [Електронний ресурс]. - Режим доступу: http://www.acrada.gov.ua/doccatalog/document/16741935/Visnovok_2012.pdf

9. Переробка винограду та виробництво виноматеріалів у 2015 році. Експрес-випуск від 14.01.2016 р. №2/0/06.2вн-15. Державна служба статистики України [Електронний ресурс]. - Режим доступу: http://www.ukrstat.gov.ua

10. Галузева Програма розвитку виноградарства та виноробства України на період до 2025 року. Наказ Мінагрополітики України, Української академії аграрних наук від 21.07.2008 року № 444/74 [Електронний ресурс]. - Режим доступу: http://search.ligazakon.ua/1_doc2.nsf/link1/FIN40145.html

11. Попова М.М. Сучасний стан і тенденції розвитку виноградарсько - виноробної галузі в Україні / М.М. Попова // Вісник Харківського національного аграрного університету. - 2013. - №4. - С.199 - 207.

12. Державний реєстр сортів рослин придатних для поширення в Україні на 2015 рік. Державна ветеринарна та фітосанітарна служба України. - К., 2015. - 467 с. 